\title{
Plated TOPCon solar cells \& modules with reliable fracture stress and soldered module interconnection
}

\author{
Sven Kluska ${ }^{1,{ }^{*}}$ (D) Benjamin Grübel ${ }^{1}$, Gisela Cimiotti ${ }^{1}$, Christian Schmiga $^{1}$, Heinrich Berg ${ }^{1}$, Andreas Beinert $^{1}$, \\ Irene Kubitza ${ }^{2}$, Paul Müller ${ }^{2}$, and Torsten Voss ${ }^{2}$ \\ ${ }^{1}$ Fraunhofer Institute for Solar Energy Systems (ISE), Heidenhofstraße 2, 79110 Freiburg, Germany \\ 2 Atotech Deutschland GmbH, Erasmusstraße 20, 10553 Berlin, Germany
}

Received: 30 June 2021 / Received in final form: 15 October 2021 / Accepted: 2 November 2021

\begin{abstract}
This work demonstrates that the application of plated $\mathrm{Ni} / \mathrm{Cu} / \mathrm{Ag}$ contacts for TOPCon solar cells and modules is a reliable alternative to screen-printed metallization. Key advantages of plated metallization is a significant reduction of material costs [B. Grübel et al., in Proceedings 11th SiliconPV Conference, Hamelin, 2021, to be published] due to the substitution of a fully printed silver finger by a stack of a thin nickel seed layer (0.5-1 $\mu \mathrm{m}$ height), highly conductive copper finger (3-10 $\mu \mathrm{m}$ height) and an ultra-thin surface finish by tin (1-3 $\mu \mathrm{m}$ height) or silver ( $<0.5 \mu \mathrm{m}$ height). In this study it will be shown that conventional soldering technology can be used to interconnect plated TOPCon solar cells. We manufactured a 60 -cell module using industrial processes. The right choice of plating electrolyte allows low stress and ductile metal finger leading to similar reliability in cell breakage experiments compared to state-of-the-art screen-printing metallization.
\end{abstract}

Keywords: c-Si solar cells / passivated contact / metallization / plating

\section{Introduction}

The learning curve of state-of-the-art passivated emitter and rear cells (PERC) [1] is flattening towards cell efficiencies above 24\%. The introduction of solar cell designs with passivated contact such as tunnel oxide passivated contact (TOPCon) solar cells is one possible solution to achieve cell efficiencies of $25 \%$ and above [2]. The industrial transition from PERC to TOPCon solar cells is currently ongoing $[1,3]$ and mostly realized with a solar cell design shown in Figure 1. The TOPCon design comes along with the replacement of aluminium based contacts (PERC) with highly conductive metal contacts such as silver or copper on the rear side. Recent publications pointed out that the application of silver based contacts on front and rear side of the solar cell will eventually lead to significant restrictions in silver supply for a growing PV market heading towards a Terawatt scale within the next ten years $[4,5]$. Hallam et al. showed that this limitation can't be overcome with the current perspective of technological improvements of silver screen printing estimated by the ITRV roadmap [6]. Recent publications showed that the combination of laser structuring the electrically insulating anti reflective

\footnotetext{
* e-mail: sven.kluska@ise.fraunhofer.de
}

coating (ARC) and plating of nickel, copper and silver can be successfully implemented in the fabrication sequence of bifacial TOPCon solar cells $[7,8]$.

This work evaluates the implementation of plated TOPCon solar cells in PV modules and takes a closer look at the impact of cell breakage depending on the metallization type. Former publications raised concerns that nonoptimized plating may raise the risk of increased internal stress in the plated contacts [9]. This work demonstrates that this concern can be eliminated by the right choice of plating electrolyte and plating conditions.

\section{Experimental}

Industrial TOPCon precursors (M6 wafer area $24,623 \mathrm{~mm}^{2}$, pseudo square) similar to Figure 1 were metallized at Fraunhofer ISE with a combination of laser patterning the ARC and plating. The reference samples were metallized by printing of silver-aluminium and silver pastes on front and rear side, respectively. The solar cells featured a grid design with 5 busbars $(0.9 \mathrm{~mm})$ and 121 and 157 fingers on the front and rear side, respectively. The finger width was about $40 \mu \mathrm{m}$ for screen printing and $20-25 \mu \mathrm{m}$ for plating. Figure 2 shows a top view microscope image of a plated finger with a finger width of $24 \mu \mathrm{m}$ and a finger height of $10 \mu \mathrm{m}$. The laser contact opening underneath the plated finger features a width of about $15 \mu \mathrm{m}$. Due to the application of an optimized 


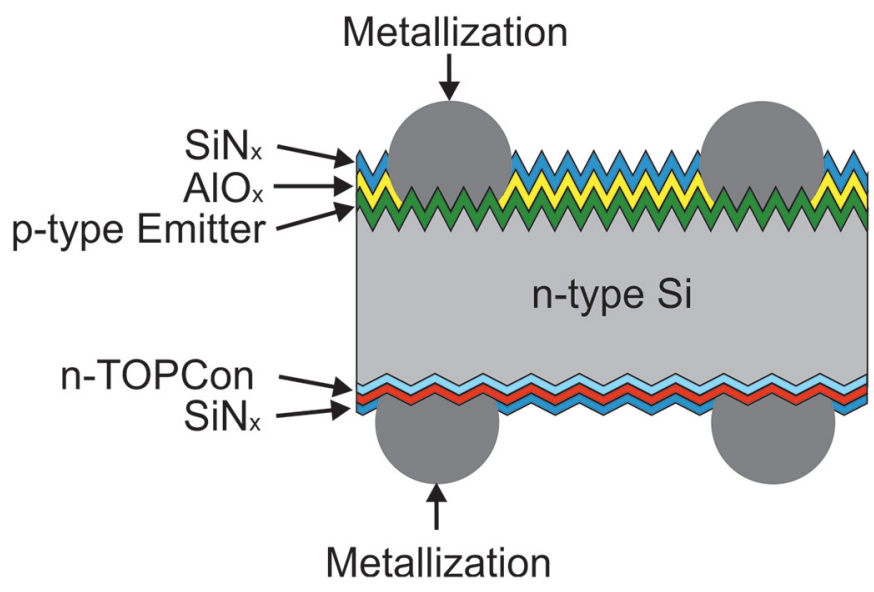

Fig. 1. Schematic of a metallized bifacial TOPCon solar cell.

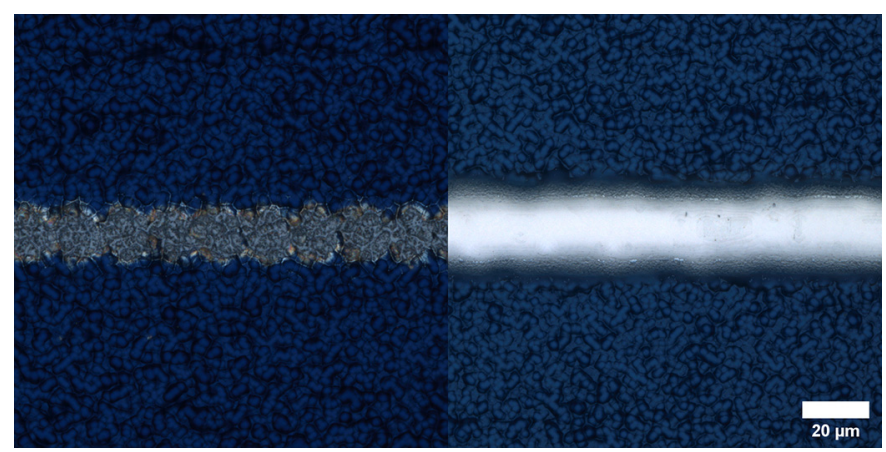

Fig. 2. Top view microscope image of the laser contact opening (left) with a width of about $15 \mu \mathrm{m}$ and a plated $\mathrm{Ni} / \mathrm{Cu} / \mathrm{Ag}$ finger with a finger height of $10 \mu \mathrm{m}$ and a finger width of $24 \mu \mathrm{m}$ (right).

$\mathrm{Cu}$ plating electrolyte supplied by Atotech Group the finger growth is anisotropic featuring an added width due to plating of about $5 \mu \mathrm{m}$ per side and $10 \mu \mathrm{m}$ in height. The according aspect ratio of the added finger growth in terms of plating height/width per side equals $2: 1$ compared to an isotropic growth of $1: 1$.

The metallized solar cells were measured at an industrial type flash IV tester. The fracture strength was determined by a 4-point bending strength test on a Zwick Roell zwicki Z0.5 TN according to DIN SPEC 91351:2017. The solar cells were tested on the front and rear side parallel to the busbar orientation with $80 \mathrm{~mm}$ outer roller span and $40 \mathrm{~mm}$ inner roller span. The sample deflection was measured by machine position and force was measured using a $50 \mathrm{~N}$ force gauge.

For both metallization types, a 60-cell PV module was fabricated using industrial processes. For both metallization types, the same soldering process was used on the stringer TT1800 from Teamtechnik. Also, the same lamination process on the vacuum laminator $Y P S A$ TOR122-5 HKV from Bürkle was used for both metallization types. A $3.2 \mathrm{~mm}$ glass with a transparent backsheet and EVA were used. After fabrication, both modules were characterized by IV using Pasan HighLIGHT LMT measurements with a measurement uncertainty of $1.8 \%$.
Furthermore, single cell mini modules with solder interconnection and lamination on both sides (without glass) were fabricated to measure the electrical properties of the solar cells/module after cell breakage.

\section{Results and discussion}

The manufactured bifacial TOPCon solar cells with either plated or screen-printed metallization were first IV measured, sorted regarding IV parameters and divided in two groups. The first group was used for 4-point bending tests to measure the fracture stress of metallized solar cells and the second group was interconnected using conventional soldering interconnection and laminated in either single cell modules or one 60 cell module for each metallization type. In the following the results of each experiment are presented.

\subsection{Solar cell IV results}

The plated solar cells in Figure 3 show an average cell efficiency $(\eta)$ benefit of $0.4 \%$ abs. compared to the screen printed (SP) reference solar cells. The main advantage is in short circuit current density $\left(j_{s c}\right)$ due to less shading of the narrow plating fingers and increased fill factor $(F F)$. The open circuit voltage $\left(V_{o c}\right)$ of the plated solar cells is slightly decreased compared to the screen-printed reference due to non-optimized laser contact opening (LCO). Current experiments at Fraunhofer ISE show that this decrease can be significantly reduced by decreased LCO width and optimized laser settings. The nickel interface layer features low contact resistivity to boron emitter and TOPCon surface, which results in contact resistance improvement (not shown here). Furthermore, the low line resistance of $\mathrm{Cu}$ plated finger also improves the grid resistance for the plated solar cells. The series resistance $\left(R_{s}\right)$ of the plated solar cells could be lowered to $0.5 \Omega \mathrm{cm}^{2}$ compared to $0.6 \Omega \mathrm{cm}^{2}$ for screenprinting. Series resistance analysis showed that this improvement was mostly caused by decreased grid resistance of the plated contacts.

The IV solar cell results demonstrate that in this experiment the introduction of plated $\mathrm{Ni} / \mathrm{Cu} / \mathrm{Ag}$ contacts shows in average an increased performance compared to the state-of-the-art screen-printed reference. The applicability of plated contacts for TOPCon solar cells as shown in this work is also confirmed by a recent publication of Kluska et al. were on industrial TOPCon precursors maximum cell efficiencies of $23.3 \%$ was demonstrated [7].

\subsection{Module results}

The fabricated 60 cell modules with bifacial TOPCon solar cells with either plated or screen-printed metallization and transparent backsheet are shown in Figure 4. The IV measurements of the modules are summarized in Table 1. The module IV results show a similar power (difference is within the measurement uncertainty) at the maximum power point $\left(P_{\mathrm{mpp}}\right)$ for both modules. The slight differences in $J_{s c}$ and $V_{o c}$ visible in Figure 3 are diminished in the 

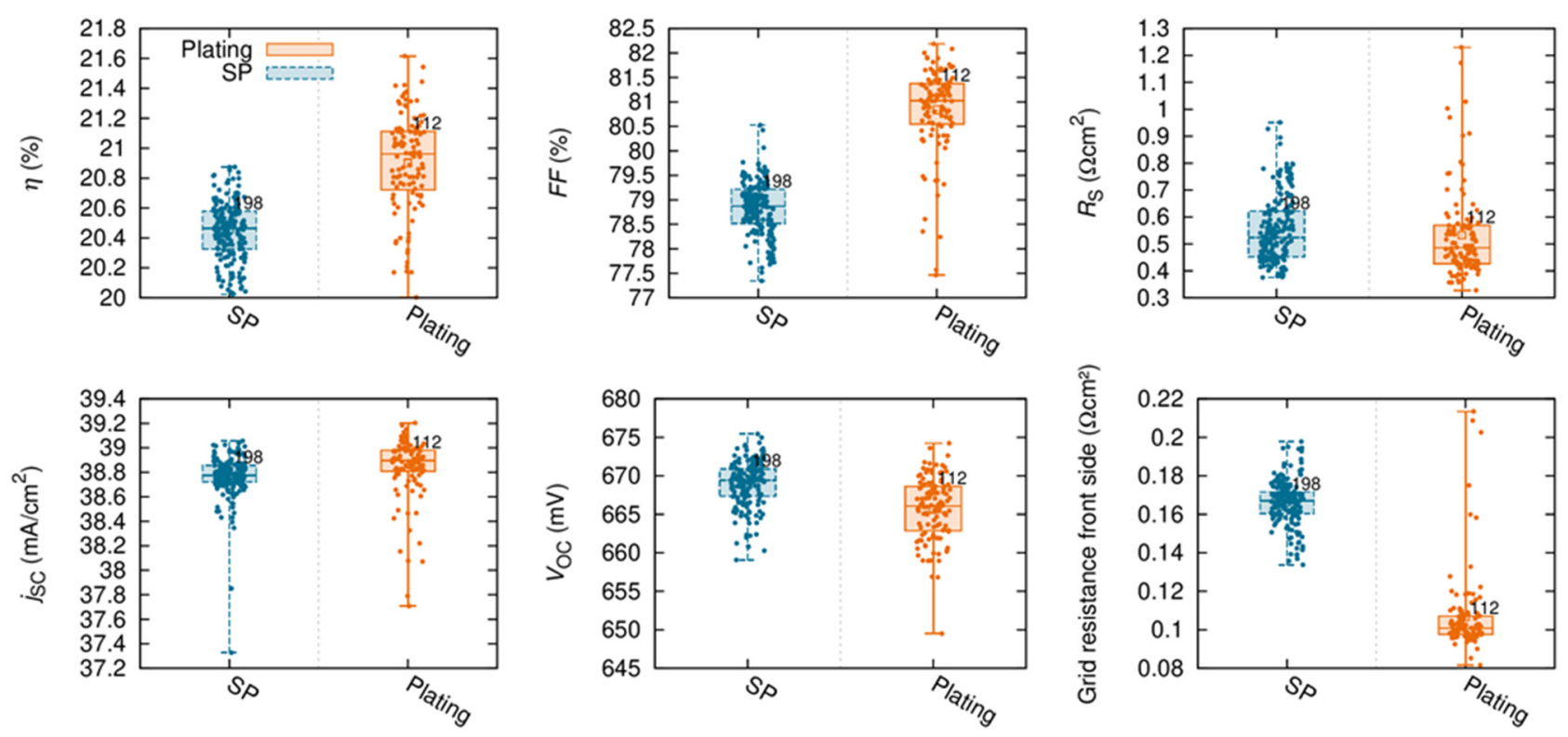

Fig. 3. IV results for plated and screen-printed (SP) bifacial TOPCon solar cells.

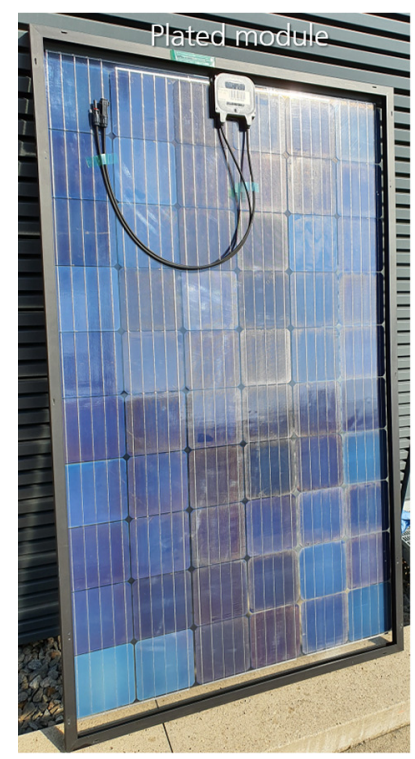

(a)

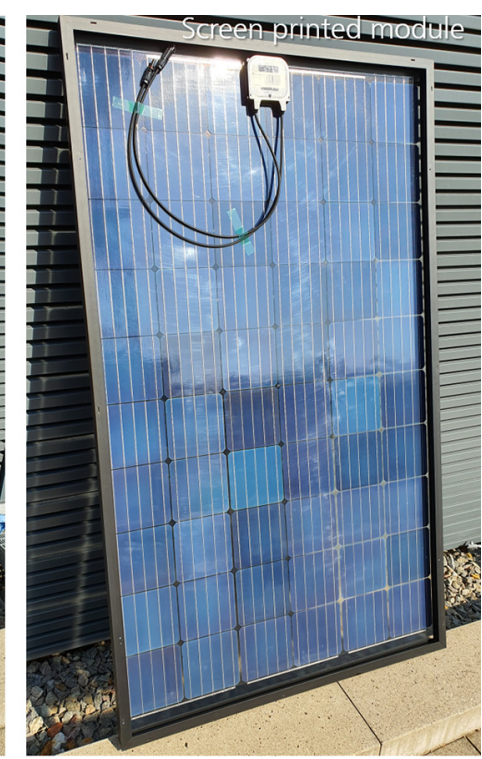

(b)

Fig. 4. Photograph of the rear side of a 60 cell module with bifacial TOPCon solar cells with either plated $\mathrm{Ni} / \mathrm{Cu} / \mathrm{Ag}$ metallization (a) or screen printed $\mathrm{AgAl} / \mathrm{Ag}$ metallization (b).

module IV due to rather large binning during IV sorting because of a low number of total cells. The only significant advantage which is retained on module level is the improved FF for the plated cells/modules.

The module IV results demonstrate that plated $\mathrm{Ni} / \mathrm{Cu} /$ Ag contacts can be successfully implemented to fabricate bifacial TOPCon modules and are a possible replacement for silver screen printed contacts.

\subsection{Reliability}

3.3.1 4-point bending test of metallized solar cells

As shown by Kaule et al. [10,11] and Kohn et al. [12] the metallization process can be governing the strength of silicon solar cells. 4-point bending tests were performed to determine the fracture stress of bifacial TOPCon solar cells. This analysis wants to answer the question if plated metallization increases the risk of wafer breakage.

The blue data in Figure 5 show the fracture stress of bifacially screen printed TOPCon solar cells. There are slight improvements in fracture stress for backside measurements but overall the value range is similar or slightly better than measurements known from PERC solar cells [11]. The orange data show the measured fracture stress of bifacially plated $\mathrm{Ni} / \mathrm{Cu} / \mathrm{Ag}$ solar cells plated with an electrolyte supplied by Atotech Group developed to achieve low internal stress in the plating deposition. The fracture stress is in the same range as in the case of bifacially printed TOPCon solar cells and agrees well with literature data from Kaule et al. [11]. This shows that the applied plating process for bifacial TOPCon solar cells did not increase the risk of wafer breakage compared to screen printed TOPCon solar cells or state-of-the-art PERC solar cells.

Single cell modules without glass but with soldering interconnection and lamination on both sides were also measured in 4-point bending tests. The mini modules were IV characterized before and after interconnection/ lamination and 4-point bending. The $F F$ results before and after cell breakage are shown in Figure 6 . The average values are calculated from six mini modules of each metallization type. For both metallization types the $F F$ decreases after interconnection and cell breakage. There is no significant difference between the metallization 
Table 1. IV module results of the plated or screen-printed (SP) bifacial TOPCon modules shown in Figure 4.

\begin{tabular}{llllllll}
\hline Modul & $I_{\mathrm{sc}}[\mathrm{A}]$ & $V_{\mathrm{oc}}[\mathrm{V}]$ & $I_{\mathrm{mpp}}[\mathrm{A}]$ & $V_{\mathrm{mpp}}[\mathrm{V}]$ & $P_{\mathrm{mpp}}[\mathrm{W}]$ & $F F[\%]$ & $\eta[\%]$ \\
\hline SP module & 9.5 & 40.2 & 8.9 & 32.6 & 291 & 76.1 & 16.96 \\
Plated module & 9.4 & 39.9 & 8.7 & 33.3 & 289 & 77.0 & 16.80 \\
\hline
\end{tabular}

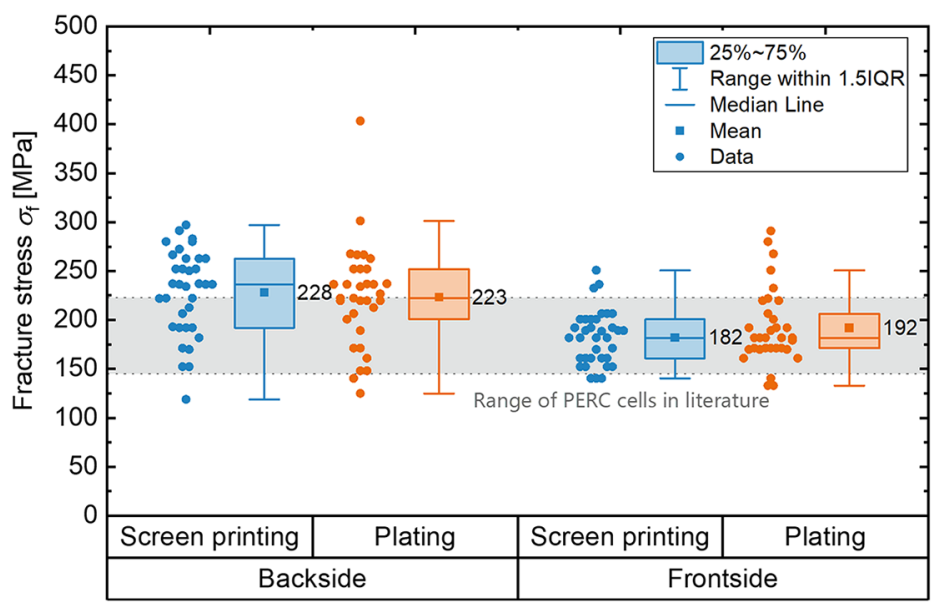

(a)

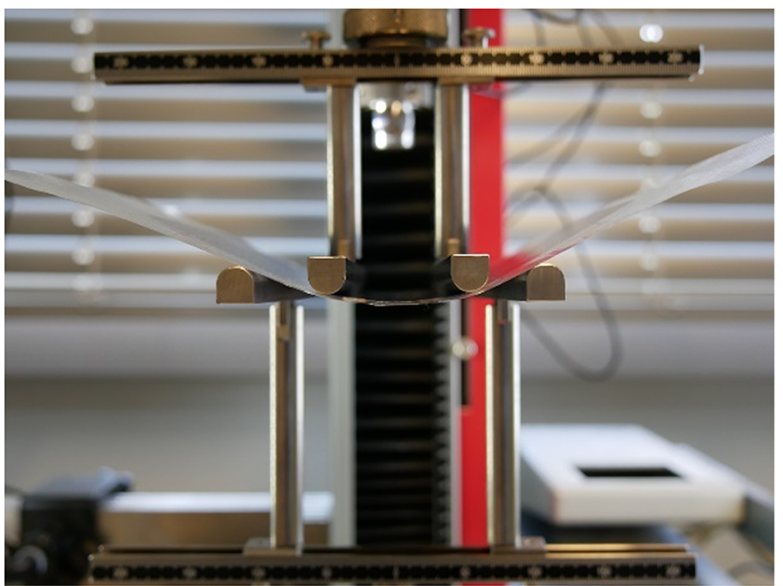

(b)

Fig. 5. Measured fracture stress of the front and rear side of bifacial TOPCon solar cells with either screen printed AgAl(front side)/ $\mathrm{Ag}$ (rear side) or plated $\mathrm{Ni} / \mathrm{Cu} / \mathrm{Ag}$ metal contacts (a). The grey area in (a) represents a typical fracture stress regime of PERC solar cells from literature [11]. The right image (b) shows the 4-point bending test of a bifacially plated TOPCon solar cell.

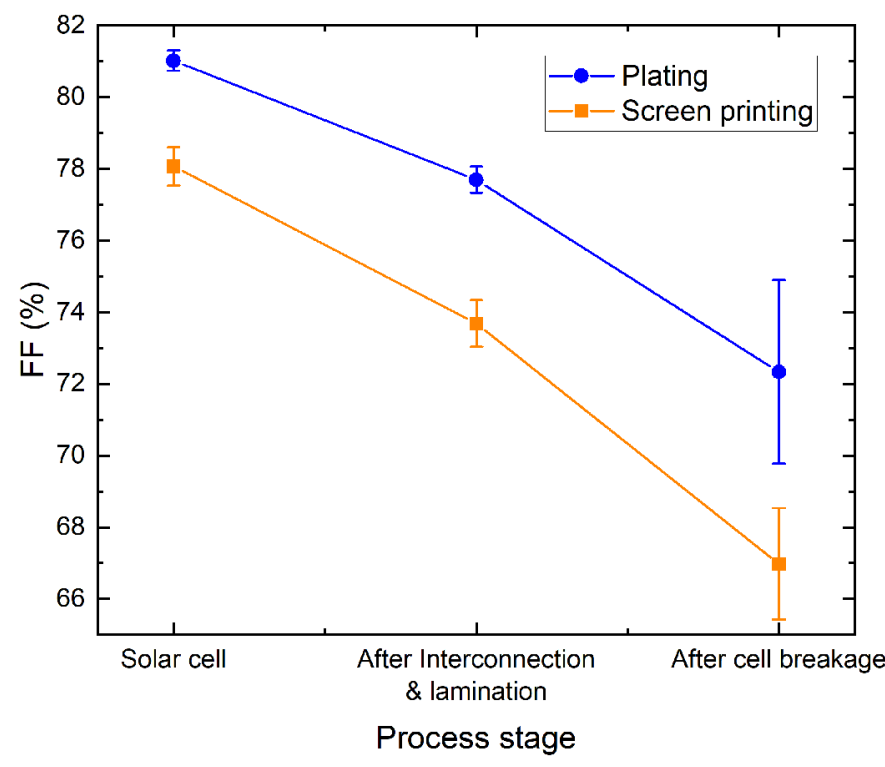

Fig. 6. Measured fill factor for solar cells before and after module fabrication and 4-point bending testing according to the metallization type.

types in the $F F$ evolution for each stage visible. The overall $F F$ improvement for plated contacts is similar to Figure 3 and stays constant after interconnection and cell breakage.

\subsubsection{Adhesion of plated contacts}

Büchler [13], Mondon [14] and Shen et al. [15] presented a comprehensive analysis on how to achieve and manipulate reliable contact adhesion of plated contacts on silicon solar cells. There are two approaches to achieve reliable contact adhesion either by thermal silicidation of the nickel-silicon interface or by laser-induced nano roughening of the silicon before plating. In this work the second approach was applied by using a UV-picosecond laser for LCO formation. As shown by Büchler the laser-induced surface features (ripples) of the LCO, in the case of ultra-short pulse laser systems, form under-cut structures to interlock the plated finger on the silicon surface. One important factor to achieve interlocking under-cut structures is also the presence of a vertical microstructure on the silicon surface such as random pyramids, iso-texture or post etched versions (emitter etch isolation) of these textured surfaces. Furthermore, a proper etching of the interfacial oxide layer within the LCO is necessary to provide contact adhesion.

The solar cells of this work were prepared with the bestknown method at Fraunhofer ISE including UV-ps LCO formation and $\mathrm{HF}$ pre-treatment before $\mathrm{Ni}$ plating to remove the native and laser-induced interface oxide layer within the LCO. A tape test of the plated contacts on the front and rear side were successfully passed. No quantitative measurements of pull force measurements or shear force measurements were performed since sufficient contact adhesion was achieved with soldered module interconnection of the plated busbars. 


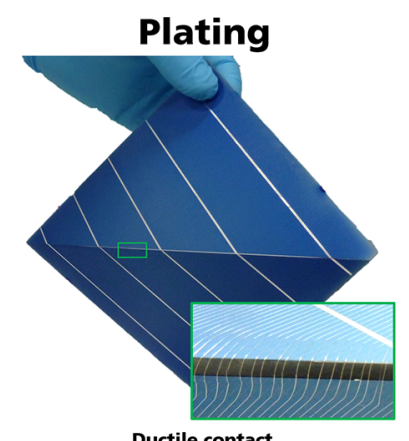

Screen printing

$\rightarrow$ Electrical contact even after cell brealkage $\rightarrow$ Electrical disconnection (finger interruption)

Fig. 7. Photographs of plated and screen-printed bifacial TOPCon solar cells after cell breakage with intact plating fingers (ductile) and electrically disconnected screen printing fingers (brittle).

\subsubsection{Advantages of ductile plating metallization}

The right choice of electrolyte and plating conditions allows the deposition of ductile $\mathrm{Ni} / \mathrm{Cu} / \mathrm{Ag}$ fingers. In comparison to brittle contacts such as screen printing this has the advantage that even in the case of cell breakage the finger is still intact and ensures an electrical connection of the broken parts. This is demonstrated by mechanical wafer breakage of bifacial TOPCon solar cells shown in Figure 7 . The benefit of ductile contacts has to be further analysed in long term stability measurements on module level. Looking only at the FF measurements broken single cell modules in Figure 6 it appears as the lamination ensures the contact cohesion even for the brittle screen printing contacts after cell breakage. Further studies have to show if ductile contacts may improve module reliability on the long-term scale especially for broken cell in thermal cycling or damp heat testing. The cross-section interface of broken contacts inhibits the risk of corrosion/oxidation, which may increase series resistance due to decreased finger conductivity for broken cells. Further investigation of plated modules after cell breakage have to analyse if the cohesive force within a plated finger leads to a local finger delamination around the ruptured trench and how this would affect the electrical performance of the solar module.

\section{Conclusion}

Industrial TOPCon solar cell precursors were used to analyze the difference of plated $\mathrm{Ni} / \mathrm{Cu} / \mathrm{Ag}$ metallization and screen-printed $\mathrm{Ag} / \mathrm{AgAl}$ metallization on solar cell efficiency, module power and mechanical stability. Plated contacts show in this experiment an improvement in cell efficiency due to increased fill factors/lowered series resistances. The fabrication of 60 -cell PV modules with each metallization type showed that this $F F$ improvement is also visible on module level. However, in terms of module power both metallization types showed a similar level. 4-point bending tests demonstrated that with the right choice of plating electrolyte and plating conditions the application of plated metallization ensures the same mechanical strength of bifacial TOPCon solar cells as for screen printed TOPCon or PERC solar cells. Furthermore, the ductility of plated contacts avoids any tearing apart of the plated finger after cell breakage as in the case of brittle screen-printed contacts. Further studies are necessary to analyze the impact of ductile and brittle contact properties on the module reliability.

One of the main drivers of this work is the question how to solve sustainability problems regarding silver consumption in an upcoming terawatt PV market. The successful implementation of plated contacts for TOPCon solar cells and modules in this work demonstrates that the substitution of silver by plated copper offers an alternative metallization solution with significantly reduced silver consumption ( $\sim 1 \% \mathrm{Ag}$ consumption compared to screen printing) or even silver-free for a plated stack of $\mathrm{Ni} / \mathrm{Cu} / \mathrm{Sn}$. The substitution with plated copper showed similar or better results in solar cell efficiency, module power and mechanical reliability.

\section{Author contribution statement}

Sven Kluska: Experiment design, data evaluation, coordination, paper writing. Benjamin Grübel: Plating processes development and execution, cell processing \& characterization. Gisela Cimiotti Plating processes development and execution. Christian Schmiga: Plating processes development. Heinrich Berg: Module characterization. Andreas Beinert: Experiment design, module fabrication, mechanical characterization. Irene Kubitza: Plating processes development and execution. Paul Müller: Plating processes development and execution. Torsten Voss: Experiment design, Plating processes development and execution. All Co-Authords participated in the discussions and reviewed the paper.

This work was supported by the German Federal Ministry for Economic Affairs and Energy in the projects "TALER" (contract no. 03EE1021B).

\section{References}

1. J. Müller, M. Schaper, I. Höger, F. Frühauf, B. Klöter, F. Fertig, S. Wasmer, K. Petter, E. Jarzembowski, M. Junghänel, C. Klenke, A. Weihrauch, M. Schley, K. Kim, A. Schwabedissen, M. Kauert, K. Duncker, J. Cieslak, R. Hönig, J. Scharf, F. Kersten, C. Ke, C. Baer, L. Niebergall, S. Schulz, S. Peters, A. Mette, M. Fischer, Q-Cells' way to solar cell efficiencies exceeding $24 \%$ in mass production, in Proceedings 11th SiliconPV Conference, Hamelin (2021), to be published

2. A. Richter, R. Müller, J. Benick, F. Feldmann, B. Steinhauser, C. Reichel, A. Fell, M. Bivour, M. Hermle, S. W. Glunz, Design rules for high-efficiency both-sidescontacted silicon solar cells with balanced charge carrier transport and recombination losses, Nat Energy 6, 429 (2021)

3. D. Chen, Y. Chen, Z. Wang, J. Gong, C. Liu, Y. Zou, Y. He, Y. Wang, L. Yuan, W. Lin, R. Xia, L. Yin, X. Zhang, G. Xu, Y. Yang, H. Shen, Z. Feng, P.P. Altermatt, P.J. Verlinden, $24.58 \%$ total area efficiency of screen-printed, large area 
industrial silicon solar cells with the tunnel oxide passivated contacts (i-TOPCon) design, Solar Energy Mater. Solar Cells 206, 110258 (2020)

4. M. Kim, Y. Zhang, P. Verlinden, B. Hallam, Towards sustainable silicon PV manufacturing at the terawatt level, in Proceedings 11th SiliconPV Conference, Hamelin (2021), to be published

5. P.J. Verlinden, Future challenges for photovoltaic manufacturing at the terawatt level, J. Renew. Sustain. Energy 12, 53505 (2020)

6. ITRPV consortium, International Technology Roadman for Photovoltaic (ITRPV): Results 2020 (2021), 12th edn

7. B. Grübel, S. Kluska, G. Cimiotti, C. Schmiga, V. Arya, B. Steinhauser, B. Goraya, S. Nold, M. Hermle, M. Kamp, M. Passig, M. Sieber, D. Brunner, Plating Metallization for Bifacial i-TOPCon Silicon Solar Cells, in Proceedings 11th SiliconPV Conference, Hamelin 2021, to be published

8. B. Grübel, G. Cimiotti, V. Arya, T. Fellmeth, F. Feldmann, B. Steinhauser, S. Kluska, T. Kluge, D. Landgraf, M. Glatthaar, Plated $\mathrm{Ni} / \mathrm{Cu} / \mathrm{Ag}$ for TOPCon solar cell metallization, in Proceedings of the 36th European Photovoltaic Solar Energy Conference and Exhibition, EU PVSEC, 2019, https://doi. org/10.4229/EUPVSEC20192019-2BO.2.3

9. N. Song, W. Zhang, P.C. Hsiao, X. Wang, Z. Li, J. Colwell, A. Lennon, Self-annealing behavior and rapid thermal processing of light induced plated copper fingers on silicon solar cells, in 2017 IEEE 44th Photovoltaic Specialist
Conference, PVSC 2017, https://doi.org/10.1109/ PVSC.2016.7749974

10. F. Kaule, W. Wang, S. Schoenfelder, Modeling and testing the mechanical strength of solar cells, Solar Energy Mater. Solar Cells 120, 441 (2014)

11. F. Kaule, S. Meyer, S. Schoenfelder, Benchmarking mechanical strength data for new solar cell concepts, in 33rd European Photovoltaic Solar Energy Conference and Exhibition (2017), pp. 276-279

12. C. Kohn, R. Kübler, M. Krappitz, G. Kleer, I. Reis, M. Retzlaff, D. Erath, D. Biro, Influence of the metallization process on the strength of silicon solar cells, in Proceedings of the 24th European Photovoltaic Solar Energy Conference and Exhibition, EUPVSEC, 2009, https://doi.org/10.4229/ 24thEUPVSEC2009-2CV.2.4

13. A. Büchler, Interface study on laser-structured plated contacts for silicon solar cells, Dissertation, Fraunhofer Verlag; Fraunhofer IRB-Verlag; Fraunhofer ISE, Freiburg/ Brsg, Stuttgart (2019)

14. A. Mondon, Nickel silicide from plated nickel for high adhesion of fully plated silicon solar cell metallization: Dissertation (Fraunhofer Verlag, Stuttgart, 2015)

15. X. Shen, P.C. Hsiao, B. Phua, A. Stokes, V.R. Gonçales, A. Lennon, Plated metal adhesion to picosecond laser-ablated silicon solar cells: influence of surface chemistry and wettability, Solar Energy Mater. Solar Cells 205, 110285 (2020)

Cite this article as: Sven Kluska, Benjamin Grübel, Gisela Cimiotti, Christian Schmiga, Heinrich Berg, Andreas Beinert, Irene Kubitza, Paul Müller, Torsten Voss, Plated TOPCon solar cells \& modules with reliable fracture stress and soldered module interconnection, EPJ Photovoltaics 12, 10 (2021) 